American Journal of Pharmaceutical Education 2018; 82 (10) Article 5980.

\title{
REVIEW
}

\section{Review of National and International Accreditation of Pharmacy Programs in the Gulf Cooperation Council Countries}

\author{
Fadi M. Alkhateeb, PhD, MBA, BSPharm, ${ }^{\mathrm{a}}$ Steve Arkle, PhD, ${ }^{\mathrm{b}}$ Sharon L. K. McDonough, PhD, ${ }^{\mathrm{c}}$ \\ David A. Latif, MBA, $\mathrm{PhD}^{\mathrm{d}}$ \\ ${ }^{a}$ College of Pharmacy, Qatar University, Doha, Qatar \\ ${ }^{\mathrm{b}}$ Commission for Academic Accreditation, Abu Dhabi, United Arab Emirates \\ ${ }^{c}$ College of Pharmacy, University of Tennessee Health Science Center, Memphis, Tennessee \\ ${ }^{\mathrm{d}}$ School of Pharmacy, University of Charleston, Charleston, West Virginia \\ Submitted August 4, 2016; accepted June 5, 2018; published December 2018.
}

Objective. To compare the different philosophies, emphases and processes of national and international accreditation paths available to pharmacy programs in Gulf Cooperation Council (GCC) countries. To identify engagement of GCC pharmacy programs with International Pharmacy Accreditation or Certification (IPAC) and the outcome advantages of IPAC compared to other national accreditation standards.

Findings. National quality standards across the GCC countries are similarly structured but in different stages of development. Pharmacy specific standards are absent. Of the 44 institutions identified offering pharmacy degrees, only three out of 28 of those in the Kingdom of Saudi Arabia (KSA) and all but two out of 15 elsewhere in the GCC, have national program-level accreditation. Nine of the institutions have IPAC via either the Accreditation Council for Pharmacy Education-International Services Program (ACPE-ISP), the Canadian Council for Accreditation of Pharmacy Programs (CCAPP) or the German Accreditation Agency in Health and Social Sciences (AHPGS). None of the institutions have sought accreditation from the Australian Pharmacy Council (APC). IPAC may serve as a tool to provide specific recognition of the quality of pharmacy programs and to enhance the quality of pharmacy education in the region.

Summary. In the absence of national bodies to accredit pharmacy initial training degrees, IPAC has become increasingly popular in the GCC countries. There are distinct regional differences in uptake and choice of IPAC. IPAC may serve as a tool to provide specific recognition of the quality of pharmacy programs and to enhance the quality of pharmacy education in the region in the absence of an unmet for pharmacy-specific national accreditation.

Keywords: international accreditation, pharmacy education, Gulf Cooperation Council (GCC) countries, ACPE certification program, national accreditation

\section{INTRODUCTION}

Since the turn of the century, few regions in the world have experienced an explosive growth in higher education as the Gulf Cooperation Council (GCC) countries. ${ }^{1}$ The GCC is a political and economic union established in 1981. It consists of six countries in the Arabian Gulf: Bahrain, Kuwait, Oman, Qatar, the Kingdom of Saudi Arabia (KSA), and the United Arab Emirates (UAE). These countries are often referred to as the "Gulf States." There has been a rapid expansion within these countries in

Corresponding Author: Fadi M. Alkhateeb. Office of Academic Affairs - Pharmacy, P.O. Box 2713, College of Pharmacy, Qatar University, Doha, Qatar. Tel: +974 44035606. E-mail: falkhateeb@qu.edu.qa the number of pharmacy schools and pharmacy initial training programs. Many pharmacy colleges in the area have started to seek international pharmacy accreditation/ certification (IPAC) believing that quality assurance resulting from successful IPAC will enhance GCC institutions' strategic strength toward labor force development, and economic sustainability. ${ }^{1-4}$

As part of the GCC trends related to quality assurance and assessment in higher education in general, pharmacy schools have witnessed significant changes in the $21^{\text {st }}$ century. With the initiation of continuous revision and standardization processes of pharmacy curricula throughout the world, the focus has been on delivering quality education to students. ${ }^{5}$ Among GCC pharmacy schools, the concept of " assessment, quality assurance 


\section{American Journal of Pharmaceutical Education 2018; 82 (10) Article 5980.}

and improvement" and "accreditation" in pharmacy education is somewhat new, as typical pharmacy curricula and universities were established only half a century ago. During this time, many major changes have occurred in the dimension of "quality of pharmacy education" to run with the education systems in North America and Europe. Recently, many pharmacy colleges in the GCC implemented a new outlook, namely " programs accreditation." This philosophy states that: "it is obligatory on every college to accredit its program(s) both nationally and internationally." Based on this philosophy, many KSA university rectors, for example, appoint vice rectors for development and quality improvement. In addition, they often create new positions at each college at the vice dean level for quality and planning. The development of accreditation standards in GCC countries has formalized regulatory requirements for a culture of quality assurance and quality improvement and, explicitly or implicitly, changes in the organizational structure of higher education institutions to develop specialist units dedicated to quality assurance and institutional research.,

Typically, international pharmacy schools adopt one of four IPAC programs: Accreditation Council for Pharmacy Education - International Services Program (ACPE-ISP), Canadian Council for Accreditation of Pharmacy Programs (CCAPP), German Accreditation Agency in Health and Social Sciences (AHPGS), or Australian Pharmacy Council (APC). ACPE offers certification, while the other three agencies offer accreditation or international accreditation.

There are 44 pharmacy colleges and schools in the GCC that offer a variety of pharmacy programs (Table 1). Recently, Kuwait started a new postgraduate PharmD program but plans to create a standalone (entry-topractice) PharmD program in $2020 .{ }^{8}$ Kuwait University College of Pharmacy expects to apply to CCAPP by 2021. At the time of this writing, the University of Bahrain had established the first program of pharmacy in the Kingdom of Bahrain. ${ }^{9}$ In the GCC, over two-thirds ${ }^{11}$ of pharmacy graduates prefer to work in hospitals rather than in community pharmacies. While clinical and hospital pharmacies in the GCC are well established and clinical pharmacists are well compensated, community pharmacy is seen as a less attractive employment option than hospital pharmacy. ${ }^{4,10-12}$ Plans to enhance the status of community pharmacy practice in the GCC are ongoing. ${ }^{5}$

Recently, many pharmacy colleges in the GCC (especially in KSA, Kuwait and Qatar) have adopted a more clinical-oriented pharmacy curriculum. Thus, most of the new pharmacy colleges, especially in KSA, are opening only PharmD programs. Some, such as Kuwait, are phasing out their bachelor of pharmacy programs. A major reason for this trend is the increasing demand for clinical pharmacists in hospitals. ${ }^{13}$ In contrast, there is limited PharmD provision in the UAE where national health authorities accord BSc and PharmD qualifications the same standing in the Professional Qualifications Requirements document. This document specifies and regulates the qualifications required for employment at various ranks as a pharmacist; most undergraduate pharmacy programsare bachelors and most postgraduate programs are masters.$^{14}$

This paper explores regulation and quality assurance in the GCC countries. It presents an overview of the various national and international regulatory frameworks for pharmacy education that have been adopted by these countries. The paper concludes with recommendations to adopt a process whereby the quality of pharmacy education in the GCC may be consistently evaluated and recognized globally. The specific objectives for this study are to: review the national and international pharmacy accreditation avenues that are available in the GCC countries and to describe the outcome advantages and limitations of IPAC compared to the domestic national accreditation standards.

\section{METHODS}

Systematic analysis was used to identify universities in the GCC area that offer pharmacy degrees and the type of accreditation program that they have adopted. Articles related to pharmacy education and accreditation in the GCC were identified via searches of the PubMed and International Pharmaceutical Abstracts databases from January 2016 to April 2018. Search terms included national accreditation, international pharmacy accreditation, pharmacy education in GCC, APC, ACPE, and CCAPP. In addition, an internet search was performed to identify articles in the media related to this topic. Online searches were conducted using the advanced search options of Google and Google Scholar.

\section{RESULTS}

Table 1 provides a profile of the pharmacy schools in the GCC. There are notable differences in this profile among countries; whereas, KSA is the sole location where there is a preponderance of institutions that only offer PharmDs, an award that is not offered in Oman and Bahrain and that is only offered by two UAE universities (one as an undergraduate, the other as a postgraduate award). KSA universities that offer pharmacy master's awards are limited but these are commonplace elsewhere in the region where they are graduate-entry programs rather than the European model of undergraduate integrated masters. Only two universities specifically offer pharmacy $\mathrm{PhDs}$. 
American Journal of Pharmaceutical Education 2018; 82 (10) Article 5980.

Table 1. Comparison of Pharmacy Colleges in the GCC Countries

\begin{tabular}{|c|c|c|c|c|}
\hline Country & $\begin{array}{c}\text { University Name, Year Pharmacy } \\
\text { College Established }\end{array}$ & Type & Degrees Offered and Credit Rating & $\begin{array}{c}\text { Accreditation/ } \\
\text { Certification }\end{array}$ \\
\hline Qatar & Qatar University, 2008 & Public & $\begin{array}{l}\text { BPharm } 173 \mathrm{CH} \\
\text { MSc Pharm } 33 \mathrm{CH} \\
\text { PharmD } 209 \mathrm{CH}\end{array}$ & $\begin{array}{l}\text { (N): None } \\
\text { (I): CCAPP-I } \\
\text { 2018-2023 }\end{array}$ \\
\hline Bahrain & University of Bahrain, 2017* & Public & BSPharm $143 \mathrm{CH}$ & None \\
\hline Kuwait & Kuwait University, 1997* & Public & $\begin{array}{l}\text { BPharm } 154 \mathrm{CH} \\
\text { MSc Pharm Sci } 33 \mathrm{CH} \\
\text { PharmD grad entry } 66 \mathrm{CH}\end{array}$ & $\begin{array}{l}\text { (N): NBAQ } \\
\text { (I): CCAPP } \\
\text { (Pending) }\end{array}$ \\
\hline \multirow[t]{3}{*}{ Oman } & $\begin{array}{l}\text { Nizwa College of Pharmacy and } \\
\text { Nursing, } 2002\end{array}$ & Private & BPharm $149 \mathrm{CH}$ & $(\mathrm{N})$ : OAAA \\
\hline & Oman Medical College, 2001 & Private & BPharm $143 \mathrm{CH}$ & $(\mathrm{N})$ : OAAA \\
\hline & Sultan Qaboos University, 2003 & Public & $\begin{array}{l}\text { MSc ( } 24 \mathrm{CH}+\text { thesis) and } \mathrm{PhD} \text { in Biomed } \\
\text { Sci, majoring in Clinical Pharmacy }\end{array}$ & (N): OAAA \\
\hline \multirow[t]{10}{*}{ UAE } & University of Sharjah, 2005 & Private & $\begin{array}{l}\text { BPharm } 170 \mathrm{CH} \\
\text { MPharm ( } 3 \text { tracks }) 36 \mathrm{CH}\end{array}$ & $(\mathrm{N}): \mathrm{CAA}$ \\
\hline & Ajman University, 1996 & Private & $\begin{array}{l}\text { BPham } 150 \mathrm{CH} \\
\text { MSc Pharm (2 tracks) } 36 \mathrm{CH}\end{array}$ & $\begin{array}{l}(\mathrm{N}): \text { CAA } \\
\text { (I) ACPE ISP }\end{array}$ \\
\hline & $\begin{array}{l}\text { Ras Al Khaimah Medical and Health } \\
\text { Sciences University, } 2007\end{array}$ & Private & $\begin{array}{l}\text { BPharm } 145 \mathrm{CH} \\
\text { MSc Pharm ( } 3 \text { tracks) } 40-44 \mathrm{CH}\end{array}$ & $(\mathrm{N}): \mathrm{CAA}$ \\
\hline & City University College of Ajman, 2011 & Private & BPharm $150 \mathrm{CH}$ & $(\mathrm{N}): \mathrm{CAA}$ \\
\hline & Gulf Medical University, 2008 & Private & PharmD $196 \mathrm{CH}$ & $\begin{array}{l}\text { (N): CAA } \\
\text { (I) ACPE ISP } \\
\text { (pending) }\end{array}$ \\
\hline & Dubai Pharmacy College for Girls, 1992 & Private & $\begin{array}{l}\text { BPharm } 164 \mathrm{CH} \\
\text { MPharm (2 tracks) 36-40 CH }\end{array}$ & $(\mathrm{N}): \mathrm{CAA}$ \\
\hline & Fatima College of Health Sciences, 2006 & Private & BPharm $141 \mathrm{CH}$ & $(\mathrm{N}): \mathrm{CAA}$ \\
\hline & $\begin{array}{l}\text { Al Ain University of Science and } \\
\text { Technology, 2006-07 }\end{array}$ & Private & $\begin{array}{l}\text { BPharm } 160 \mathrm{CH} \\
\text { MSc Pharm 36CH }\end{array}$ & $\begin{array}{l}\text { (N): CAA } \\
\text { (I): ACPE ISP }\end{array}$ \\
\hline & Higher Colleges of Technology, 2010 & Public & BPharm $132 \mathrm{CH}$ & $(\mathrm{N}): \mathrm{CAA}$ \\
\hline & UAE University, 2010 & Public & PharmD grad entry $52 \mathrm{CH}$ & $(\mathrm{N}): \mathrm{CAA}$ \\
\hline \multirow[t]{10}{*}{ KSA } & Al Jouf University, 2007 & Public & $\begin{array}{l}\text { B.Pharm } 163 \mathrm{CH} \\
\text { PharmD } 218 \mathrm{CH}\end{array}$ & None \\
\hline & Al Baha University, 2011-12 & Public & PharmD & None \\
\hline & King Saud University, 2001 & Public & $\begin{array}{l}\text { BPharm } 174 \mathrm{CH} \\
2 \mathrm{MScs} 26 \mathrm{CH}+\text { thesis } / 43 \mathrm{CH} \\
\text { PharmD } 205 \mathrm{CH} \\
\text { PhD }\end{array}$ & $\begin{array}{l}(\mathrm{N}) \text { : None } \\
\text { (I): ACPE ISP } \\
\text { (I): CCAPP-I } \\
\text { (Expired on June } \\
2017 \text { ) }\end{array}$ \\
\hline & King Abdulaziz University, 1964 & Public & $\begin{array}{l}2 \mathrm{MScs} 32-35 \mathrm{CH} \\
\text { PharmD } 214 \mathrm{CH}\end{array}$ & $\begin{array}{l}\text { (N): None } \\
\text { (I): CCAPP-I } \\
2017-2023\end{array}$ \\
\hline & Umm Al-Qura University, 2006 & Public & $\begin{array}{l}\text { BPharm } 180 \mathrm{CH} \\
\text { PharmD } 221 \mathrm{CH}\end{array}$ & $\begin{array}{l}(\mathrm{N}) \text { : None } \\
(\mathrm{I}) \text { : AHPGS }\end{array}$ \\
\hline & Taibah University, 2006 & Public & $\begin{array}{l}\text { BPharm } 181 \mathrm{CH} \\
\text { PharmD } 218 \mathrm{CH}\end{array}$ & None \\
\hline & Jazan University, 2009-10 & Public & Pharm D $218 \mathrm{CH}$ & None \\
\hline & Taif University, 2006 & Public & PharmD & None \\
\hline & Qassim University, 2004 & Public & PharmD $195 \mathrm{CH}$ & $\begin{array}{l}(\mathrm{N}): \text { NCAAA } \\
\text { (I): ACPE ISP }\end{array}$ \\
\hline & Najran University, 2007 & Public & $\begin{array}{l}\text { BPharmSci } 164 \mathrm{CH}+960 \text { hours clinical } \\
\text { placement }\end{array}$ & None \\
\hline
\end{tabular}


American Journal of Pharmaceutical Education 2018; 82 (10) Article 5980.

Table 1. (Continued)

\begin{tabular}{|c|c|c|c|c|}
\hline Country & $\begin{array}{c}\text { University Name, Year Pharmacy } \\
\text { College Established }\end{array}$ & Type & Degrees Offered and Credit Rating & $\begin{array}{l}\text { Accreditation/ } \\
\text { Certification }\end{array}$ \\
\hline & $\begin{array}{l}\text { King Saud University for Health } \\
\text { Sciences, 2007-08 }\end{array}$ & Public & PharmD $219 \mathrm{CH}$ & None \\
\hline & Al Faisal University, 2016 & Private & PharmD $198 \mathrm{CH}$ & None \\
\hline & $\begin{array}{l}\text { Prince Sattam bin Abdulaziz University, } \\
2009\end{array}$ & Public & BPharm Sci $170 \mathrm{CH}$ & None \\
\hline & University of Tabuk, 2013 & Public & PharmD $215 \mathrm{CH}$ & None \\
\hline & University of Dammam 2011 & Public & PharmD $228 \mathrm{CH}$ & None \\
\hline & Northern Borders University, 2010-11 & Public & PharmD $214 \mathrm{CH}$ & None \\
\hline & $\begin{array}{l}\text { Riyadh College of Dentistry and } \\
\text { Pharmacy, } 2004\end{array}$ & Private & $\begin{array}{l}\text { BPharmSci } 168 \mathrm{CH} \\
\text { MSc Clin Pharm and Pharm D }\end{array}$ & $(\mathrm{N}): \mathrm{NCAAA}$ \\
\hline & Batterjee Medical College, 2007-08 & Private & PharmD $205 \mathrm{CH}$ & None \\
\hline & $\begin{array}{l}\text { Almaarefa Colleges for Science \& } \\
\text { Technology, } 2008\end{array}$ & Private & $\begin{array}{l}\text { PharmD } 171 \mathrm{CH}+48 \text { weeks } \\
\text { clinical placement }\end{array}$ & None \\
\hline & King Faisal University, 2005-06 & Public & PharmD $174 \mathrm{CH}$ & $\begin{array}{l}\text { N): None } \\
\text { (I): ACPE ISP } \\
\text { (I): CCAPP-I } \\
2018-2022\end{array}$ \\
\hline & Shaqra University , 2014 & Public & PharmD & None \\
\hline & Buraydah Private Colleges, 2008 & Private & BPharmSci $177 \mathrm{CH}$ & None \\
\hline & King Khalid University, 2001 & Public & $\begin{array}{l}\text { BPharmSci } 171 \mathrm{CH} \\
\text { PharmD } 198 \mathrm{CH}\end{array}$ & None \\
\hline & $\begin{array}{l}\text { Imam Abdulrahman Bin Faisal } \\
\text { University, } 2013\end{array}$ & Public & PharmD & None \\
\hline & $\begin{array}{l}\text { Mohammed Al-Mana College of Health } \\
\text { Sciences, } 2008\end{array}$ & Private & BPharm & None \\
\hline & Hail University, 2011 & Public & PharmD & None \\
\hline & $\begin{array}{l}\text { Princess Nourah bint Abdulrahman } \\
\text { University, } 2007\end{array}$ & Public & PharmD $210 \mathrm{CH}$ & None \\
\hline & $\begin{array}{l}\text { Ibn Sina National College for Medical } \\
\text { Science, } 2002\end{array}$ & Private & PharmD $197 \mathrm{CH}$ & N: NCAAA \\
\hline
\end{tabular}

Abbreviations: CH credit hours; UAE, United Arab Emirates; KSA, Kingdom of Saudi Arabia; (N), national accreditation; (I), international accreditation/certification; NBAQ, National Bureau for Academic Accreditation; OAAA, Oman Academic Accreditation Authority; CAA, Commission for Academic Accreditation; NCAAA, National Commission for Academic Accreditation and Assessment; CCAPP-I: International, Canadian Council for Accreditation of Pharmacy Programs;; ACPE-ISP, Accreditation Council for Pharmacy Education - International Services Program; AHPGS, German Accreditation Agency in Health and Social Sciences; NI, no information

Other regional differences are observed in the extent of national accreditation: a large majority of KSA pharmacy programs are not nationally accredited; a large majority of the programs in other GCC countries have received national accreditation. While many colleges or schools intend to pursue IPAC, some with more than one agency, few have already been internationally accredited or certified.

\section{National Accreditation in the GCC}

Compared to many Western systems for the regulation of pharmacy initial education programs in which the role of pharmacy regulators includes accreditation of these programs, pharmacy regulatory bodies do not accredit pharmacy programs in the GCC countries. This is undertaken by national authorities that are responsible for accreditation of a broad range of education programs across many disciplines, to which a common national set of standards is applied. The first country in the GCC to establish an accreditation agency was the UAE. The Commission for Academic Accreditation (CAA) was established in 2000. Accreditation of programs in licensed institutions is granted based on compliance with standards. The CAA standards cover both institutional licensure and program accreditation with different but overlapping application of standards for initial licensure, re-licensure, initial accreditation and re-accreditation. ${ }^{15}$ Shortly after the UAE established its accreditation body, Oman established the Oman Academic Accreditation Authority (OAAA), which also uses separate but related 


\section{American Journal of Pharmaceutical Education 2018; 82 (10) Article 5980.}

standards for accreditation of institutions and programs. ${ }^{16,17}$ In 2004, KSA developed the National Commission for Academic Accreditation and Assessment (NCAAA). The NCAAA has institutional and programmatic versions of standards. ${ }^{18,19}$ As reported in Table 1, out of more than 24 pharmacy schools in KSA, three were accredited, both of the accredited schools are private colleges. Bahrain University recently opened its first pharmacy program in the country (2016/2017). The quality of this pharmacy school is assessed by the Quality Assurance Authority for Education and Training (QQA), which was established in 2008. It has conducted institutional reviews and is now undertaking a cycle of program review, the outcomes of which are confidence statements against quality indicators. ${ }^{20,21}$ In Kuwait, the National Bureau for Academic Accreditation (NBAQ) was established in 2010. Whereas standards for institutional accreditation have been developed, program-level accreditation standards are not published. ${ }^{22}$ Among the GCC countries, Qatar is the only one that relies almost exclusively on foreign accreditation processes for its single pharmacy school. Further information on the characteristics and operations of the above bodies within the broader context of quality assurance and accreditation in Arab states is available in the scoping studies of the Arab Network for Quality Assurance in Higher Education (ANQAHE). ${ }^{23}$

In comparison to the NCAAA, OAAA and QQA standards, CAA standards are the most comprehensive, detailed and prescriptive. Whereas the NCAAA, OAAA and QQA standards are generally phrased in qualitative terms, the CAA standards place quantitative requirements in some key areas such as on-entry qualification grades for admissions to programs and study load limitations in respect to non-standard entry, faculty qualifications and experience, maximum faculty workloads, CGPA required for graduation and minimum credit hours for programs. They also include stipulations that provide considerable detail on matters such as the required content of key documents including handbooks, catalogs, manuals and course files.

Among the GCC standards for program accreditation, NCAAA and CAA re-accreditation standards are the most closely aligned in terms of organization and structure while the QQA standards are the least similar (Table 2). There are several quality indicators that are included in NCAAA, CAA and OAAA standards that are absent from QQA's standards, but these are included in QAA's standards for institutional review (structured into domains of mission, planning and governance, academic standards, quality assurance and enhancement, quality of teaching and learning, student support, human resources, infrastructure, physical and other resources, research, and community engagement) which are more closely aligned with NCAAA, CAA and OAAA's standards. $^{20,21}$

All of the program-level standards encompass policies and procedures, planning, risk management, entry standards, curriculum, course-and program-level outcomes and delivery, academic integrity, pedagogy, fiscal, human and physical resources and their management and development, external relations, institutional research, quality assurance and enhancement (including external benchmarking), student records, services and conduct, health and safety and public information. They also consider management and administration of programs and mission, but the QQA standards place least emphasis on governance. They have a narrower focus than the others, and these and the OAAA standards (which recognize the interrelationship of teaching and research) lack the consideration of the organization's research activities. The QQA standards stand alone in lack of explicit consideration of service, of student appeal and of grievance procedures. The NCAAA and OAAA standards make explicit statements about provisions for disabled students. This is dealt with indirectly in the CAA standards that refer to compliance with labor laws. The NCAAA standards are the only ones to contain statements about equal provision for male and female students. Whereas all the standards encourage external benchmarking, the NCAAA standards require that the key performance indicators identified by the commission should be included in the benchmarking process. $^{24,25}$ All of the accreditation agencies employ expert reviewers who are otherwise independent of the agency and of the programs to be accredited. They maintain a register of reviewers and NCAAA, OAAA and QQA publish criteria for external reviewers and guidance on roles and responsibilities. ${ }^{14,17,20}$ Criteria are similar for the three agencies and include experience and expertise (eg, in quality management and review, curriculum development, academic leadership, research, scholarship and service, subject and/ or professional practice expertise) relevant to duties, credibility, integrity, ethical principles, team working skills, professional judgment, analytical skills, sensitivity to context and local culture, commitment to quality assurance, and currency. Criteria for appointment of external reviewers are not published by CAA but it is the authors' experience that similar criteria to those used by other accrediting agencies are informally applied. Reviewers are required to sign confidentiality agreements. They are briefed on-site but not given comprehensive training as it is expected or required that they will have previously undertaken relevant training elsewhere. 
American Journal of Pharmaceutical Education 2018; 82 (10) Article 5980.

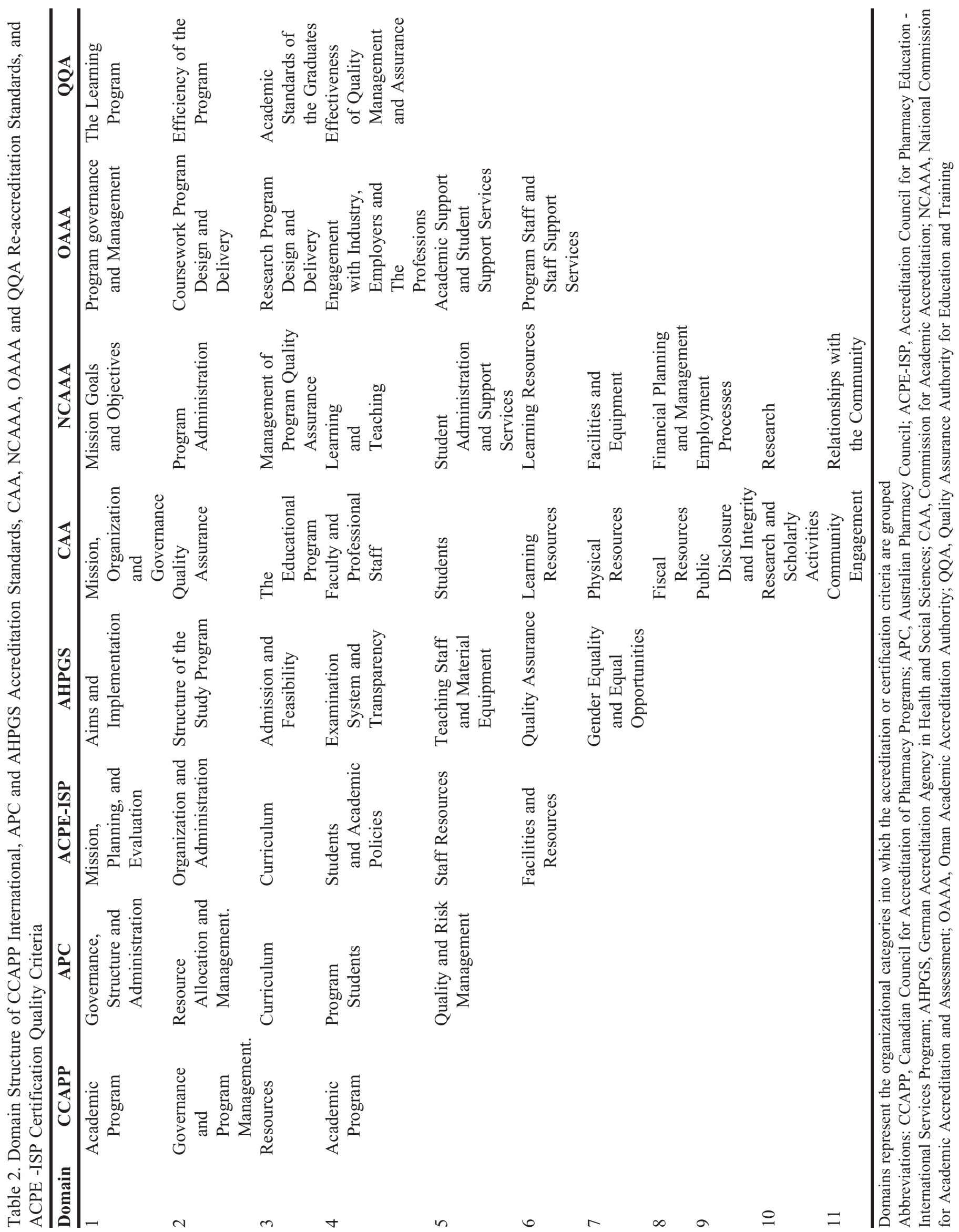




\section{American Journal of Pharmaceutical Education 2018; 82 (10) Article 5980.}

The standards include reference to outcomes-based national qualification frameworks in determining award level. ${ }^{26-29}$ These differ in terms of classification of levels and awards and detailed description of outcomes at each level, but, except for KSA, they similarly classify outcomes into knowledge, skills and competency domains (with differences as to which outcomes are classified to which domains). KSA's framework defines four domains of knowledge: cognitive skills, interpersonal skills and responsibility, and communication, information technology, and numerical skills, with a provision of an additional domain of psychomotor skills where applicable. The frameworks contain guidance on credit volume expected for each award, based either on the US (KSA and UAE) credit hour system or the UK (Bahrain and Oman) credit accumulation transfer system (30 credit hours or 120 credits, respectively, equivalent to one year of fulltime study).

Subject benchmark statements and indicative syllabi for initial education programs in pharmacy are not developed in GCC countries; therefore, they are not available as reference tools in accreditation processes. The closest approach to reference to locally developed, pharmacyspecific standards is found in KSA where NCAAA has published specific outcomes for professional programs including pharmacy. ${ }^{30}$

\section{International Pharmacy Accreditation}

The CCAPP, APC, ACPE-ISP, and the AHPGS are accreditation institutions that are internationally recognized for their high academic standards. An important element of this investigation is to analyze these four organizations as to what their purpose, mission, and costs are. Whereas CCAPP, APC and ACPE-ISP only accredit/ certify pharmacy education (Table 3 ), AHPGS accredits a broader range of programs.

\section{Canadian Council for Accreditation of Pharmacy Programs (CCAPP)}

CCAPP was established in 1993 through the assistance of the Canadian government to ensure that educational standards and criteria were being met. ${ }^{31}$ The first set of CCAPP standards was an adaptation, with assistance from ACPE, of the ACPE standards that existed at that time. The Association of Faculties of Pharmacy of Canada (AFPC) has recommended entry-to-practice (PharmD) programs for all pharmacy schools in Canada by the year 2020 and accreditation standards for the first professional degree in pharmacy were revised to include standards for the entryto-practice PharmD programs. These went into effect in January 2013. ${ }^{32,33}$ Institutions that have not already moved to an entry-level program are actively committing resources to doing so. The main objective of the CCAPP is to appraise the pharmacy programs in Canada while evaluating the quality improvement of pharmaceutical degree programs. The 2013 CCAPP accreditation standards document contains 35 standards built upon outcomes for educational programs articulated by the AFPC and organized into four domains. ${ }^{32}$ More recently, new standards have been published for 2018. ${ }^{33}$ The new document includes 30 standards organized into three domains: academic program, governance and program management, and resources (Table 2). The 2018 standards do not represent wholesale change, but they are a development and reorganization of the 2013 standards.

A different set of 24 standards is used for international accreditation. ${ }^{34}$ These mirror the 2018 standards except that they reference collaboration and teamwork, intra- and interprofessional collaborative practice skills. Competencies as care providers, communicators, collaborators, leader-managers, health advocates, scholars and in professional roles are diluted in the curriculum standards. Requirements for interprofessional and practice are retained and a requirement for the curriculum to broaden understanding of roles and competencies of pharmacists and other health professionals is added. Similarly, the standards for universities to integrate and endorse the concept of interprofessional education and collaborative practice and to embed these in policies and plans is absent from the international standards as is the requirement for formalized agreements with practice sites. Other differences include adjustment to the detail of curriculum requirements, reference to expectations of local national bodies rather than Canadian bodies, and less prescription both of information to be provided to admission applicants (and absence of the requirement for these to be in the public domain) and of the nature of recruitment programs. There is a lack of a requirement for faculty engagement with regulatory bodies. Adjustment is made to standards on financial resources, additional criteria for contractual arrangements where programs are jointly delivered across multiple institutions. The requirement for an inclusive and non-discriminatory experience is retained, but a criterion for a just culture is absent in the international standards. The requirements for learning hours in practice settings (640 hours BSc, 1600 hours PharmD) are the same in both sets of standards and both require an academic network that also includes medicine and nursing.

Because of the differences in scope of practice of the profession within other jurisdictions, in the pharmacy laws and regulations, and in the practice experiences of the students, CCAPP added the term "international" to any level of accreditation conferred to a pharmacy school 


\section{American Journal of Pharmaceutical Education 2018; 82 (10) Article 5980.}

Table 3. Comparison Between Canadian Council for Accreditation of Pharmacy Programs, Australian Pharmacy Council and Accreditation Council for Pharmacy Education - International Services Program Accreditation/Certification Requirements

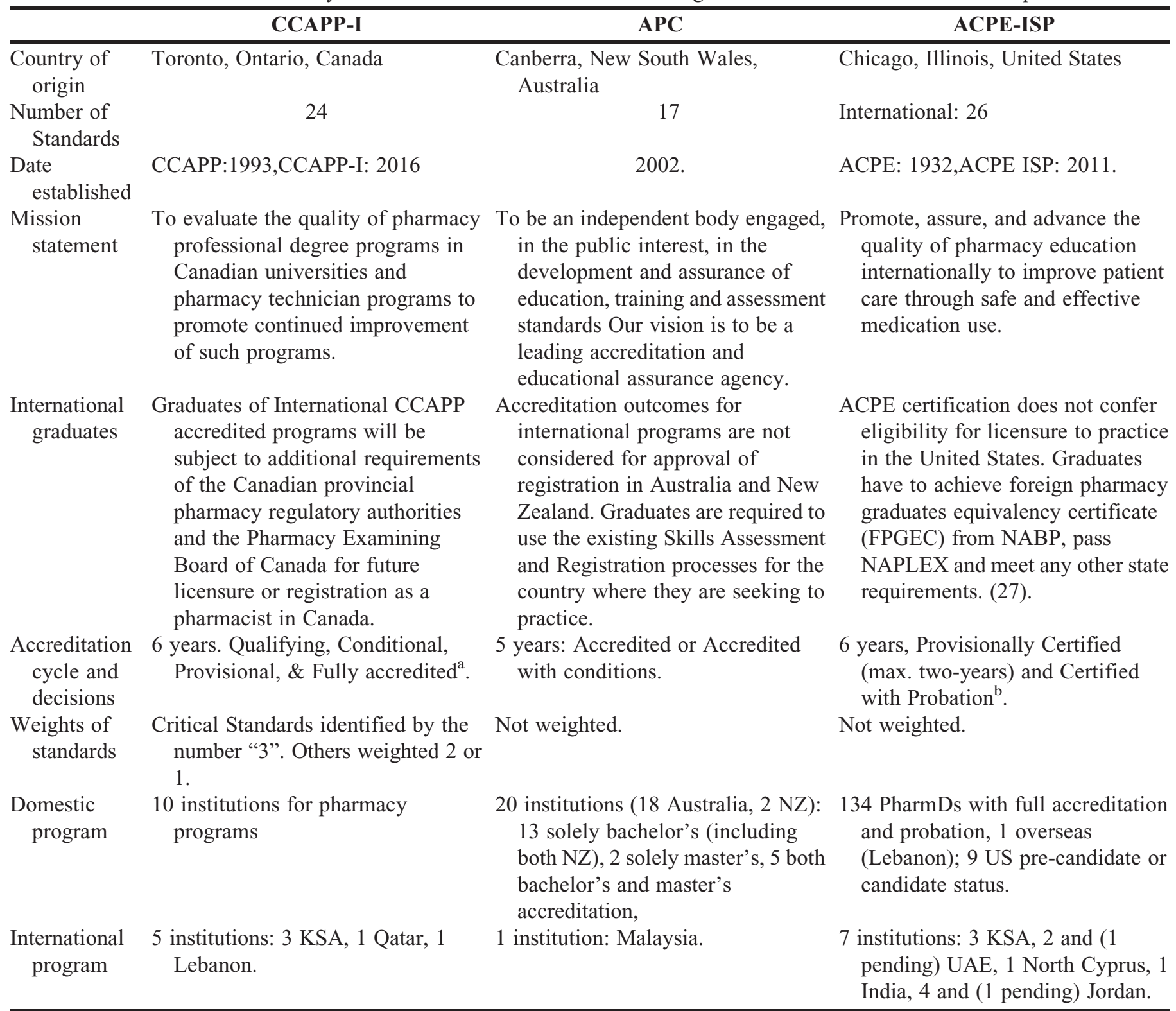

Abbreviations: CCAPP, Canadian Council for Accreditation of Pharmacy Programs; APC Australian Pharmacy Council; ACPE-ISP, Accreditation Council for Pharmacy Education - International Services Program; KSA, Kingdom of Saudi Arabia; UAE, United Arab Emirates; NZ, New Zealand; CPD, continuing professional development

${ }^{a}$ A new program that has no students enrolled but has appointed a dean; A new program that has students enrolled by has not graduated a class; Initial or continued Full Accreditation status for a six-year term for the program complies with accreditation standards

${ }^{b}$ Provisionally Certified: The Certification Status that may have factors that compromise compliance with Quality Criteria, but that has initiated appropriate plans to address such factors and meets all ACPE's requirements for such recognition. While Certified with Probation: The

Certification Status granted as being partially or non-compliant with one or more of the Quality Criteria and that has not made adequate progress towards bringing the Criterion/Criteria into compliance

based outside of Canada. The implication of this international CCAPP award for graduates toward future licensure or registration as Canadian pharmacists is that they are subject to additional requirements of the Canadian provincial pharmacy regulatory authorities and the Pharmacy Examining Board of Canada. ${ }^{34}$
The first international CCAPP-accredited college was Qatar University College of Pharmacy. In KSA, three universities have international accreditation status while one expired in June 2017 and no renewal was requested by King Saud University. ${ }^{35}$ Kuwait University announced that it will apply to CCAPP once it establishes the 


\section{American Journal of Pharmaceutical Education 2018; 82 (10) Article 5980.}

standalone PharmD program (expected 2020). Provisional accreditation is granted to a program that has students enrolled but has not graduated a class of students. Conditional accreditation is initially granted for a maximum of three years, is extendable to a longer term (not exceeding six years), and is subject to receipt of a report that satisfies the CCAPP so long as the matters giving rise to its concerns are being adequately addressed.

\section{The Australian Pharmacy Council (APC)}

Established in 2002, with the purpose of ensuring that a high level of quality in pharmacy education is maintained, the Australian Pharmacy Council (APC) accredits programs in Australia and New Zealand, and provids reviews for improvement. ${ }^{36}$ The APC undertakes accreditation of international programs against the same standards as pharmacy programs in Australia and New Zealand. Its 2014 standards document contains 17 standards. ${ }^{37}$ These are primarily concerned with programs leading to bachelor's and master's degrees and do not make specific reference to PharmD. Uptake of international accreditation to APC standards has been modest, and while there is some adoption of Australian pharmacy curriculum in the region, there are currently no programs that are accredited by APC in the GCC countries. There is not a specific time span for receiving accreditation. However, for a newly established program, the process could take as long as two and a half years. A mandatory site evaluation is required before initial accreditation can be provided, and after accreditation is received, a site evaluation is required once in every accreditation cycle (five years). Any graduate from an APC-accredited institution must use and adhere to the skills assessment and registration processes in the respective country in which the graduate intends to practice pharmacy. This skills recognition process is designed to permit overseas pharmacists to exhibit their pharmacy knowledge, skills, and competence in accordance with the guidelines set in place by Australia.

\section{Accreditation Council for Pharmacy Education (ACPE)}

The ACPE is an agency based in the United States that provides accreditation for professional pharmacy degree programs. Established in 1932, it is the sole US national accreditation agency for pharmacy education, and is the oldest pharmacy education accreditation agency in the world. For a brief time, ACPE offered accreditation of PharmD degree programs outside the US. One program (at the Lebanese American University, Lebanon) was granted accreditation, and has maintained its accreditation to this day.
ACPE approved the establishment of the International Services Program (ISP) in 2011. The ISP was created to strengthen ACPE's goal of working internationally with stakeholders to improve the field of pharmacy education and pharmacy practice. ISP's vision is to "promote, assure, and advance the quality of pharmacy education internationally to improve patient care through safe and effective medication use." ${ }^{38}$

The term "certification" rather than "accreditation" was adopted for ACPE's international activities for technical/legal reasons. This is because of the link between ACPE accreditation of degree programs and eligibility for licensure as a pharmacist that is embedded in state legislation. ACPE defines "certification" in the same way it defines "accreditation." The Certification Policies and Procedures virtually mirror the Accreditation Policies and Procedures, but they reference international quality criteria for certification rather than the accreditation standards. $^{38,39}$ The 2016 ACPE standards document has 25 standards, while the original international version had been reduced to 19. In 2016, the ACPE Board approved a re-structured version that has 26 criteria as seven of the original criteria were split into two. The certification quality criteria are also well aligned with the Quality Assurance of Pharmacy Education, the International Pharmacy Federation (FIP)'s Global Framework (2008 and 2014), a document that was validated as being globally applicable. ${ }^{40}$ Compared to the ACPE standards, which are specific to PharmD programs and all of which have to be satisfied for accreditation, the ACPE-ISP quality criteria are not specific to any single type of degree program (bachelors, masters, and professional doctorate programs may be eligible if it is linked to licensure), and there is no leeway to grant full certification status without meeting all criteria. In accordance with the Certification Decision Tree currently used by the ACPE ISP, a program for which initial Certification has been applied will only be granted Certification if all 26 Quality Criteria (QC) are "Compliant" or "Compliant with Monitoring." If there is one or more QC that are "Partially Compliant," the best status that a program can be granted would be "Provisional Certification." If there is one or more QC that are "Non Compliant" or there are multiple QC that are "Partially Compliant," the ACPE Board is likely to request the school to revise and re-submit the application. ${ }^{41}$ The key principle for the quality criteria is that they will be interpreted and applied within the national context. To this end, the document, which is organized into six sections with each section containing several criteria, is structured differently than the ACPE standards. The criteria and requirements for their satisfaction are less explicitly specified (Table 2). 


\section{American Journal of Pharmaceutical Education 2018; 82 (10) Article 5980.}

The ACPE certification process goes through different stages (initial certification, interim report, focused visit, and comprehensive visit to continue certification). There are three different statuses with ACPE certification: certified, provisionally certified, or denied. The customary review cycle (period between comprehensive on-site evaluation visits) for established certified programs is six years. The first ACPE-certified programs in the GCC were the BPharm and PharmD at King Saud University College of Pharmacy. ${ }^{41}$

The ACPE quality criteria and APC and CCAPP standards are all specific to pharmacy education. Broader consideration of US, Australian and Canadian national differences in approach to accreditation and registration of health care professionals is published by the Australian Health Practitioner Regulatory Agency but in respect of the ACPE-ISP, APC and CCAPP standards for pharmacy programs, all cover governance and organization (including mission, commitment to research and scholarship, leadership of pharmacy colleges/schools and interrelationship between colleges/schools and institution; with stronger autonomy expectations from APC and CCAPP than from ACPE-ISP); financial, physical and human resources and their evaluation and development; quality assurance and improvement; risk management or safety arrangements; planning; admissions; student services and support; student participation and representation; relationship with external organizations (including health care providers educational outcomes); curriculum and its development, assessment and management; teaching, learning and assessment; and expectations for experiential placement learning that includes rationale for placement selection in the CCAPP and ACPE-ISP documents. ${ }^{42}$ All of the standards deal to some extent with equality of opportunity/non-discrimination; this extends in the APC standards to affirmative action in respect to indigenous populations.

The APC standards provide more detailed guidance than the others on curriculum content (through description of learning domains that are not part of the standards) and the expectations of experiential placements and learning, but, unlike the CCAPP standards (and in common with ACPE-ISP), they do not specify minimum experiential learning hours. The CCAPP and APC standards either explicitly or implicitly place an expectation for early exposure of students to clinical environments, but this is not stated in the ACPE-ISP document. The Canadian standards are also explicit about interprofessional education which is not the case in the ACPE-ISP and APC documents; although the latter does refer to collaborative engagement. Whereas the APC standards deal with English language proficiencies, the other standards do not. There is an expectation from ACPE-ISP that its certified programs should have local national accreditation in consideration of national health and medication-related needs and priorities. ACPE-ISP monitors the program to ensure that national accreditation is achieved in a period acceptable to the ACPE Board. CCAPP requires that graduates have competencies to meet the entry-level scope of practice. Program duration is specified by APC by reference to the Australian Qualifications Framework CCAPP, and ACPE ISP requires that the program should equate to four years of full-time study. ACPE-ISP does not specify program duration.

Fees for ACPE, APC and CCAPP recognition are detailed on their websites and similarly structured. In 2018, ACPE adopted a tiered fee structure which takes into account a country's economic status. For this purpose, ACPE uses World Bank data (gross national income per capita) and country classifications. The ACPE Board has adopted the following tiers: Tier A: High Income Countries, Tier B: Upper Middle Income Countries, and Tier C: Lower Middle and Low Income Countries. ${ }^{41}$ At the time of writing, each one charged an application fee, a fee for the on-site visit plus recovery of travel, accommodation, subsistence, visas and other associated costs. Reaccreditation fees are not separately specified for APC and CCAPP. The APC accreditation period is up to six years; CCAPP's period is up to eight.

\section{Accreditation Agency in Health and Social Sciences (AHPGS)}

The Accreditation Agency in Health and Social Sciences (AHPGS) was founded in 2001 and has been a member of the European Consortium for Accreditation (ECA), the European Association for Quality Assurance in Higher Education (ENQA), and the International Network for Quality Assurance Agencies in Higher Education (INQAAHE) since $2004 .{ }^{43}$ It is one of 10 agencies certified by the Foundation for the Accreditation of Study Programs in Germany's Accreditation Council. It focuses on accreditation of bachelor's and master's programs in the field of health and social sciences and related areas. The founding members of the AHPGS are Nursing Sciences, Faculties of Social Work, and Therapeutic Pedagogy, as well as Public Health (AHPGS). Thirty-two nursing and allied health programs in KSA and two sociology and social work programs in Oman are accredited by the AHPGS, but Umm Al-Qura College of Pharmacy in KSA is the first pharmacy program to receive AHPGS accreditation. ${ }^{44}$

Seven criteria are used by AHPGS for the accreditation of study programs at foreign higher education institutions (Table 2). ${ }^{45}$ These are not focused to individual professional health and social science disciplines, and, in keeping with the broad range of programs to which they are applied, they are relatively general statements. The Framework for Qualifications of the European Higher 


\section{American Journal of Pharmaceutical Education 2018; 82 (10) Article 5980.}

Education Area (also known as the Bologna Qualifications Framework) is a key reference point of the criteria with expectation of an outcome competency-based approach to definition of program objectives and learning outcomes, consistency of award level with Bologna Descriptors, and modular program design in which volume of credit and definition of courses is consistent with European Credit Transfer System guidelines. ${ }^{46}$ Davies reported on the application of competence-based curricula and European Higher Education Policy. ${ }^{47}$ The criteria include emphasis on equal opportunities, including gender and special needs.

Similar terminology was adopted to describe outcomes across both the national and international accreditation processes; many use summative outcomes such as accredited, conditional, provisional, or denied. Among accrediting bodies, accreditation periods range from one to 10 years, depending on the performance of the institution or program. Many of the national and international accreditation bodies make public a list of accredited institutions or programs with an online register on their websites.

A similar format was adopted for pharmacy program accreditation site visits, which normally last from 3 to 5 days. The accrediting team is usually composed of university professors and experts in pharmacy education from US, UK, and Australia. ${ }^{48}$ The team will write an evaluation report through direct contact and meetings with leaders in the pharmacy institute, faculties, students, staff, preceptors and stakeholders. Learning resources including lecture halls, libraries, clinical skills labs, simulated pharmacies, and training sites are also investigated by the accrediting team. Teams often focus on how far pharmacy students perform the advanced pharmacy practice experience (APPE) and interprofessional education and training. Other important aspects that are examined by the accrediting team are how the educational outcomes of different courses are assessed and the relationship of course outcomes to program outcomes.

\section{DISCUSSION}

This review of both national and international accreditation paths in the GCC highlights a growing push toward quality assurance globally for pharmacy education. There is a great deal of similarity among the various accrediting standards because most follow similar processes such as self-assessment reports and peer-review visits. While they may be labeled or grouped differently, they also share many quality dimensions such as students, programs, resources and facilities, academic staff, and quality assurance and improvement. The standards for international accreditation are similar, which indicates general agreement on what constitutes quality in an educational program, or, at least agreement on the program components that should be examined to assess quality.
Since the turn of the century, many GCC countries have established national agencies for the accreditation of higher education programs and developed key standards references such as national qualification frameworks. The intended benefits of these developments include facilitation of a knowledge economy and increased international competitiveness while improving educational quality and standards that had been regarded as variable, improving stakeholder confidence in higher education, and increasing mobility. ${ }^{2,6,49}$ Substantial evidence has yet to accumulate to determine the extent to which these have been achieved, but progress toward mobility has been made through transnational recognition of academic awards from accredited programs within the GCC countries.

Whereas there has been consideration of harmonization of education quality assurance structures across the GCC states and in the wider Arabian context (eg, through one of ANQAHE's initiatives), there are notable differences between these structures among the GCC member states. $^{23,50-52}$ Pharmacy regulators in the GCC states do not publish standards for initial training programs or accredit these programs. National benchmark statements for pharmacy programs are absent: the national regulation of higher education pharmacy programs via accreditation agencies to standards that are designed to apply across all disciplines. Disciplinary and professional context is achieved by involvement of external reviewers (usually from Western countries) who have subject expertise, but the model for accreditation of pharmacy programs in GCC states is markedly different to Western models in which accreditation of such programs is undertaken by profession-specific professional regulatory bodies.

Pharmacy programs in the GCC have increasingly sought IPAC recognition. There are parallels between the direction of change of pharmacy practice in the region with less emphasis on product and an increasing focus on development of clinically-skilled, patient-focused, professionally-equipped pharmacy graduates/workforce who can function in interdisciplinary teams. ${ }^{3,11}$ This is consistent with the philosophy and emphases of the IPAC regulatory bodies. ${ }^{34,37}$ IPAC is also particularly relevant to GCC countries where there is a substantial expatriate representation with aspiration toward global mobility. An alternative and much more limited approach to determination of global equivalence in pharmacy programs, at least in respect to selected outcomes achieved by graduates, is the adoption of assessment instruments that are modelled on standards such as NAPLEX or FPGEE assessments. ${ }^{53}$

As discussed by Roberts, for IPAC standards to be effective, they must be sufficiently flexible to be contextualized with sensitivity to the locale and that accrediting agencies have a strong focus on international development 


\section{American Journal of Pharmaceutical Education 2018; 82 (10) Article 5980.}

of pharmacy education. ${ }^{54}$ ACPE and CCAPP facilitate contextualization by using variants of their national standards when considering recognition of international programs and both emphasize the developmental purpose of accreditation. Accrediting a region composed of several countries is not a one-size-fits-all situation. Choosing the appropriate international pharmacy accreditation for a pharmacy college in the GCC depends on many factors, such as the type of program (bachelor vs. PharmD), cost and budgeting, among other variables. For instance, a PharmD program (typical to KSA) in the GCC may find the ACPE-ISP or the CCAPP more appropriate to pursue than APC or AHPGS because the APC and AHPGS are less familiar with PharmD programs. In other GCC countries such as Oman and the UAE, the structure of pharmacy programs is more aligned with Australian and European models and the North American IPACs may be a less attractive option. There are, however, examples at Umm AlQura University and Al Ain University of Science and Technology of a PharmD accredited by a European body and a BPharm accredited by a North American body respectively. Stakeholder influences may also come into play: many clinical pharmacy faculty in GCC universities are PharmD graduates from US universities, and there is increasing adoption of US models of health care provision in the region as illustrated by US-managed hospitals and by institutions seeking joint commission recognition. Choice of an accrediting agency can also be influenced by previous experience such as the AHPGS, which recently accredited Umm Al-Qura University's pharmacy programs, has accredited nine other programs of that university and accredits 31 programs across five universities in $\mathrm{KSA}^{44}$

It is only recently that national accreditation systems, let alone IPAC, have been established in the GCC countries, and, given the extended timescale expected for impact of changes in educational quality assurance frameworks, there is not a substantial literature on the effects of these changes specifically on the quality of pharmacy education in the region. ${ }^{55}$ Positive impact of national accreditation on self-assessment culture, standardization of quality indicators, benchmarking, alignment of activities, faculty development and faculty and student satisfaction has, however, been reported from the oldest pharmacy college in the UAE which was the first GCC country to implement higher education accreditation. ${ }^{56}$

\section{CONCLUSION}

IPAC is becoming popular in the GCC countries and may serve as a tool to enhance the quality of pharmacy education and give confidence to stakeholders that GCC pharmacy schools meet global standards of quality. National accreditation bodies can become overwhelmed with accrediting programs such as pharmacy because many have several different national accreditation designations. A consistent, customized set of standards for each program may be more efficient and effective in garnering the confidence of stakeholders. It is our view that the national accreditation agencies of GCC countries should establish more specific standards for pharmacy education programs in collaboration with stakeholders such as pharmacy licensing boards, pharmacy graduates, employees, and employers. It is important to realize that specific areas of pharmacy education such as experiential learning cannot be fully addressed by generic standards.

\section{ACKNOWLEDGMENTS}

We sincerely thank the following individuals for their contributions to the literature review reported in this paper: Dr. Yousif Asiri, Spenser McAda and Michelle Walbeck.

\section{REFERENCES}

1. Alhamoudi A, Alnattah A. Pharmacy education in Saudi Arabia: the past, the present, and the future. Curr Pharm Teach Learn. 2018;10(1):54-60.

2. Roberts DL. Innovations in Higher Education Regulation and Quality Assurance in the Arabian Gulf: New Directions in Policy Implementation. [master's thesis]. New York, NY: Columbia University; 2011.

3. Kheir N, Zaidan M, Younes H, El Hajj M, Wilbur K, Jewesson PJ. Pharmacy education and practice in 13 Middle Eastern countries. Am J Pharm Educ. 2008;72(6):Article 133.

4. Asiri YA. Emerging frontiers of pharmacy education in Saudi Arabia: the metamorphosis in the last fifty years. Saudi Pharm J. 2011;19(1):1-8.

5. Almusallam A. Accreditation and quality assurance in postsecondary education in the kingdom of Saudi Arabia. J High Educ Sci. 2013;(3):193-199.

6. Abouammoh AM. Higher education in the GCC states: reforms and regulations. In: Hertog S, ed. National Employment, Migration and Education in the GCC. Berlin, Germany: Gerlach Press; 2012. 7. Albaqami S. Implementing quality assurance in Saudi Arabia: a comparison between the MESO and the MICRO Levels at PSU. Higher Educ Studies. 2015:5(3):66-81.

8. Kuwait University College of Pharmacy. http://www.hsc.edu.kw/ FOP/dean_msg.aspx. Accessed January 17, 2018.

9. University of Bahrain College of Allied Health. Bachelor of science in pharmacy program. http://www.uob.edu.bh/en/index.php/ colleges/college-of-health-sciences/allied-health/190-b-sc-inpharmacy. Accessed January 17, 2018.

10. Al-Wazaifi M, Matowe L, Albsoul-Younes A, Al-Omran OA. Pharmacy education in Jordan, Saudi Arabia, and Kuwait. Am J Pharm Educ. 2006:70(1):Article 18.

11. Bin Saleh G, Rezk NL, Laika L, Ali A, El-Metwally A. Pharmacist, the pharmaceutical industry and pharmacy education in Saudi Arabia: a questionnaire-based study. Saudi Pharm J. 2015: 23(5):573-580

12. Rayes IK, Hassali MA, Abduelkarem AR. Perception of community pharmacists towards the barriers to enhanced pharmacy services in the healthcare system of Dubai: a quantitative approach. Pharm Pract. 2015;13(2):506. 


\section{American Journal of Pharmaceutical Education 2018; 82 (10) Article 5980.}

13. Fathelrahman A, Ibrahim M, Wertheimer A. Pharmacy practice in Saudi Arabia. In: Pharmacy Practice in Developing Countries: Achievements and Challenges. New York, NY: Academic Press; 2016:171-195.

14. UAE Ministry of Health. Unified healthcare professional qualification requirements. Abu Dhabi, United Arab Emirates: UAE Ministry of Health; 2014;101. https://www.haad.ae/HAAD/ LinkClick.aspx? fileticket $=2 \mathrm{~K} 191 \mathrm{lpB} 6 \mathrm{jc} \% 3 \mathrm{~d} \&$ tabid $=927$. Accessed November 3, 2017.

15. UAE Commission of Academic Accreditation. Standards for licensure and accreditation. Abu Dhabi, United Arab Emirates: UAE Commission of Academic Accreditation; 2011. https://www.caa.ae/ caa/images/Standards2011.pdf. Accessed November 14, 2017.

16. Oman Academic Accreditation Authority. Institutional Standards Manual. Muscat: Oman Academic Accreditation Authority; 2016a. http://www.oaaa.gov.om/InstitutePdf/ISAM\% 20Book\%20Final.pdf. Accessed November 14, 2017.

17. Oman Academic Accreditation Authority. Program Accreditation Manual. Muscat, Oman: Oman Academic Accreditation Authority; 2016. http://www.oaaa.gov.om/ ProgramPdf/PSAM\%20draft\%20v1\%20for\%20circulation_28\% 20March\%202016.pdf. Accessed November 14, 2017.

18. KSA National Center for Academic Accreditation and Assessment. Standards for Quality Assurance and Accreditation of Higher Education Institutions. Riyadh, Saudi Arabia: National Center for Academic Accreditation and Assessment; 2015. http:// www.ncaaa.org.sa/en/Releases/StandardsDocuments/D.1.I_\% 20Standards\%20for\%20Institutions_V3_Oct2015.pdf. Accessed November 14, 2017.

19. KSA National Center for Academic Accreditation and Assessment. Standards for Quality Assurance and Accreditation of Higher Education Programs. Riyadh, Saudi Arabia: National Center for Academic Accreditation and Assessment; 2015. http://www. ncaaa.org.sa/en/Releases/StandardsDocuments/D.1.P_\%20Standards \%20for\%20Programs_V3_Oct\%202015.pdf. Accessed November 14, 2017.

20. Bahrain National Authority for Qualifications \& Quality Assurance of Education \& Training. Programmes Within-College Reviews Handbook. Manama, Bahrain: Kingdom of Bahrain Education \& Training Authority; 2014. http://www.bqa.gov.bh/En/ Mediacenter/Documents/DHR\%20(\%20PCR\%20)\%20Handbook\% 20(\%20English) \%2025.March.2015\%20(\%20Print).pdf. Accessed November 14, 2017.

21. Bahrain National Authority for Qualifications \& Quality Assurance of Education \& Training. Institutional Review Handbook. Manama, Bahrain: Kingdom of Bahrain Education \& Training Authority; 2009. http://www.bqa.gov.bh/Ar/Publications/DocLib/ HERU-ins.pdf. Accessed November 16, 2017.

22. Kuwait National Bureau for Academic Accreditation and Education Quality Assurance. Standards for Institutional Accreditation. Kuwait City, Kuwait: National Bureau for Academic Accreditation and Education Quality Assurance; 2015. http://nbaq. edu.kw/pdf/Decisions/NBAQ_Accredit_Standards_English.pdf. Accessed November 14, 2017.

23. Arab Network for Quality Assurance in Higher Education. ANQAHE Second Scoping Study, Survey of Quality Assurance and Accreditation in Higher Education in the Arab Region. Paris, France: United Nations Educational, Scientific and Cultural Organization; 2012. http://unesdoc.unesco.org/images/0023/002301/230149E.pdf. Accessed November 14, 2017.
24. KSA National Center for Academic Accreditation and Assessment. NCAAA Key Performance Indicators. Riyadh, Saudi Arabia: National Center for Academic Accreditation and Assessment; 2015. http://www.ncaaa.org.sa/en/Releases/ KeyPerformanceIndictorDocuments/Key\%20Performance\% 20Indicators.pdf. Accessed November 14, 2017.

25. KSA National Center for Academic Accreditation and Assessment. Handbook for Quality Assurance and Accreditation in Saudi Arabia, Part 3, External Reviewers for Accreditation and Quality Assurance. Riyadh, Saudi Arabia: National Center for Academic Accreditation and Assessment; 2015. http://www.ncaaa. org.sa/en/Releases/HandBookDocuments/Handbook\%20Part\%203. pdf. Accessed November 16, 2017.

26. UAE National Qualifications Authority. Qualifications Framework Emirates Handbook. Abu Dhabi, United Arab Emirates: National Qualifications Authority; 2012. http://www.qualifications. ae/pdf/QF\%20Handbook_v1b_28_Feb_2012.pdf. Accessed November 3, 2017.

27. Oman Academic Accreditation Authority. Oman Qualifications Framework. Muscat, Oman: Oman Academic Accreditation Authority; 2017. http://www.oaaa.gov.om/Docs/OQF-Ev1.pdf. Accessed November 3, 2017.

28. KSA National Center for Academic Accreditation and Assessment. National Qualifications Framework for Higher Education in the Kingdom of Saudi Arabia. Riyadh, Saudi Arabia: National Center for Academic Accreditation and Assessment; 2015. http://www.ncaaa.org.sa/en/Releases/

NationalQualifFrameworkDocuments/National\%20Qualification\% 20Framework.pdf. Accessed November 3, 2017.

29. Kingdom of Bahrain Educational Training and Quality Authority. General Directorate of National Qualifications Framework, Handbook for Institutions. Manama, Bahrain: Kingdom of Bahrain Education \& Training Authority; 2017. http://www.bqa. gov.bh/En/Publications/DocLib/NQF\%20Handbook\%20for\% 20Institutions\%20-\%202017\%20Edition.pdf. Accessed November 3, 2017. 30. KSA National Center for Academic Accreditation and Assessment. Guidelines for Program Development and Review. Program Learning Outcomes: Business, Nursing, Dentistry, Pharmacy, Engineering, Teacher Education, Medicine. Riyadh, Saudi Arabia: National Center for Academic Accreditation and Assessment; 2015. http://www.ncaaa.org.sa/en/Releases/Documents/ Guidelines\%20for\%20Professional\%20Programs.pdf. Accessed November 3, 2017.

31. Austin Z, Ensom E. Education of pharmacists in Canada. Am J Pharm Educ. 2008;72(6)Article 128.

32. The Canadian Council for Accreditation of Pharmacy Programs. Accreditation Standards for the First Professional Degree in Pharmacy Programs. Toronto, Ontario, Canada: The Canadian Council for Accreditation of Pharmacy Programs; 2014. http://ccappaccredit.ca/wp-content/uploads/2016/01/CCAPP_accred_ standards_degree_2014.pdf. Accessed November 14, 2017. 33. The Canadian Council for Accreditation of Pharmacy Programs. Accreditation Standards for the First Professional Degree in Pharmacy Programs. Toronto, Ontario, Canada: The Canadian Council for Accreditation of Pharmacy Programs; 2018. http://ccappaccredit.ca/wp-content/uploads/2016/01/Accreditation-Standardsfor-Canadian-First-Professional-Degree-in-Pharmacy-Programs.pdf. Accessed November 14, 2017.

34. The Canadian Council for Accreditation of Pharmacy Programs. International Accreditation Standards and Guidelines for First Professional Degree in Pharmacy Programs. Toronto, Ontario, 


\section{American Journal of Pharmaceutical Education 2018; 82 (10) Article 5980.}

Canada: The Canadian Council for Accreditation of Pharmacy Programs; 2017. http://ccapp-accredit.ca/wp-content/uploads/2016/ 01/International-Accreditation-Standards-for-First-ProfessionalDegree-in-Pharmacy-Programs-2017.pdf. Accessed November 14, 2017.

35. The Canadian Council for Accreditation of Pharmacy Programs. International Pharmacy Degree Programs Accredited by CCAPP. Toronto, Ontario, Canada: The Canadian Council for Accreditation of Pharmacy Programs; 2017. http://ccapp-accredit.ca/internationalprograms/list-of-international-programs. Accessed November 14, 2017. 36. Marriott JL, Nation RL, Roller L, et al. Pharmacy education in the context of Australian practice. Am J Pharm Educ. 2008;72(6): Article 131.

37. Australian Pharmacy Council. Accreditation Standards for Pharmacy Programs in Australia and New Zealand. Canberra, Australia: Australian Pharmacy Council; 2012. https://www. pharmacycouncil.org.au/policies-procedures/standards/ standards_pharmacyprograms 2014.pdf. Accessed November 14, 2017. 38. Accreditation Council for Pharmacy Education. Accreditation Council for Pharmacy Education International Service Program. International Quality Criteria for Certification of Professional Degree Programs in Pharmacy. Chicago, IL: Accreditation Council for Pharmacy Education; 2016. https://www.acpe-accredit.org/pdf/ ISP/QualityCriteria.pdf. Accessed November 14, 2017.

39. Accreditation Council for Pharmacy Education. Accreditation Standards and Key Elements for the Professional Program in Pharmacy Leading to the Doctor of Pharmacy Degree. Standards 2016. Chicago, IL: Accreditation Council for Pharmacy Education; 2016. https://www.acpe-accredit.org/pdf/Standards2016FINAL.pdf. Accessed November 14, 2017.

40. International Pharmacy Federation. Quality Assurance of Pharmacy Education: the FIP Global Framework. The Hague, The Netherlands International Pharmacy Federation. https:// www.fip.org/files/fip/PharmacyEducation/Quality_Assurance/ QA_Framework_2nd_Edition_online_version.pdf. Accessed November 14, 2017.

41. Accreditation Council for Pharmacy Education. Accreditation Council for Pharmacy Education Directory of Programs with Certification Status. Chicago, IL: Accreditation Council for Pharmacy Education; June 2018. https:/www.acpe-accredit.org/pdf/ ISP/DirectoryofCertifiedPrograms.pdf. Accessed December 9, 2018. 42. Australian Health Practitioner Regulatory Agency. Comparison of International Accreditation Systems for Registered Health Professions. Canberra, Australia: Australian Health Practitioner Regulatory Agency; 2016. http://www.ahpra.gov.au/documents/default.aspx?record $=\mathrm{WD} 17 \%$ $2 \mathrm{f} 22815 \& \mathrm{dbid}=\mathrm{AP} \& \mathrm{chksum}=452 \times \mathrm{xyoA} 39 \mathrm{cjNlbE} 0 \mathrm{cYfmTA} \% 3 \mathrm{~d} \% 3 \mathrm{~d}$.

Accessed November 14, 2017.

43. Accreditation Agency in Health and Social Sciences. Brief description of AHPGS. Freiburg, Germany: Accreditation Agency in Health and Social Sciences; 2016. http://ahpgs.de/english/. Accessed November 14, 2017.

44. Accreditation Agency in Health and Social Sciences. Reports. Freiburg, Germany: Accreditation Agency in Health and Social Sciences; 2017. http://ahpgs.de/english/reports/. Accessed November 14, 2017. 45. Accreditation Agency in Health and Social Sciences. Criteria for the assessment and accreditation procedures of study programs at foreign higher education institutions. Freiburg, Germany: Accreditation Agency in Health and Social Sciences; 2015. http:// ahpgs.de/wp-content/uploads/2011/10/Criteria_AHPGS_englisch. pdf. Accessed November 14, 2017.

46. Bologna Working Group. A Framework for Qualifications of the European Higher Education Area. Copenhagen, Denmark: Danish Ministry of Science, Technology and Innovation; 2005. http://ecahe. eu/w/images/7/76/A_Framework_for_Qualifications_for_ the_European_Higher_Education_Area.pdf. Accessed November 9, 2017.

47. Davies H. Competence-based curricula in the context of Bologna and EU higher education policy. Pharm (Basel). 2017:5(2):E17. 48. Moustafa MAA. Looking for accreditation of pharmacy programs, is it luxury or necessity? J Pharma Care Health Sys. 2015;2:e136.

49. Brandenburg T. Bridging the Knowledge Gap: Internationalization and Privatization of Higher Education in the State of Qatar and the Sultanate of Oman, [dissertation]. Mainz, Germany: Johannes Gutenberg-Universität; 2012.

50. UAE National Qualifications Authority. Qualifications Metaframeworks: A Report Supporting the Development of Gulf Cooperation Council's Gulf Qualifications Framework (GQF). Abu Dhabi, United Arab Emirates: UAE National Qualifications Authority; 2013. الخلفية تقرير إطار الخليج المؤهلات Accessed November 9, 2017.

51. Alsindi T. Qualifications Framework ANQAHE Model. Presentation to Malaysian Qualifications Agency international seminar on quality assurance of higher education, Petaling Jaya, Malaysia. 2016. http://www2.mqa.gov.my/MISQAHE/Slides/Main \%20Session/Day\%201\%20(17\%20October\%202016)/Session\% 202\%20-\%20Presenter\%202\%20-\%20Dr\%20Tariq.pdf. Accessed November 9, 2017.

52. UNESCO Institute for Life Long Learning. Global Inventory of Regional and National Qualifications Frameworks, Volume II: National and Regional Cases. Hamburg, Germany: UNESCO Institute for Life Long Learning; 2015. http://unesdoc.unesco.org/ images/0023/002351/235123e.pdf. Accessed November 9, 2017. 53. Alkhateeb FM, Clauson KA, Latif DA, Al-Rousan RM. Global education implications of the foreign pharmacy graduate equivalency examination. Am J Pharm Educ. 2010:74(5):Article 87.

54. Roberts DL. US accreditation of higher education in the Arabian Gulf: a case for standards. Gulf Research Meeting, University of Cambridge, England, July 2011. https://www.academia.edu/ 9058755/_US_accreditation_of_higher_education_in_the_ Arabian_Gulf_A_case_for_standards._Gulf_Research_ Meeting_University_of_Cambridge_England_July_6-9_2011. Accessed November 14, 2017.

55. Allais S. The implementation and Impact of National Qualifications Frameworks: Report of a Study in 16 Countries. Geneva, Switzerland: International Labour Office; 2010. https://olc. worldbank.org/sites/default/files/The $\% 20$ implementation $\% 20 \mathrm{of} \%$ 20QF\%20in \%2016\%20countries_ILO $\% 20 \% 281 \% 29$.pdf. Accessed November 14, 2017.

56. Salam S, Sherzad F. The role of accreditation standards in delivering a quality assured program experience in the UAE. Online $J$ Qual Higher Educ. 2015;2(4):88-92. 